\title{
Rozwój sektora bankowego w krajach Europy Środkowo-Wschodniej
}

\section{THE DEVELOPMENT OF THE BANKING SECTOR IN THE COUNTRIES OF CENTRAL AND EASTERN EUROPE}

Gtównym celem artykułu było określenie poziomu rozwoju sektora bankowego krajów Europy Środkowo-Wschodniej (ESW) i porównanie go do poziomu przeciętnego dla całej Unii Europejskiej oraz strefy euro. Analizie poddano zmienne dotyczace wielkości sektora, dostęności ustug bankowych, a także efektywności ekonomicznej i stabilności sektora. Obliczony na ich podstawie syntetyczny wskaźnik rozwoju sektora bankowego wykazat, że zmniejsza się zróżnicowanie w rozwoju sektora bankowego pomiędzy krajami ESW. W latach 2008-2016 większości krajów regionu zmniejszyła także dystans $w$ rozwoju sektora $w$ stosunku do średniej w Unii Europejskiej.

Słowa kluczowe: sektor bankowy, kraje Europy Środkowo-Wschodniej

\section{Wstęp}

System bankowy obejmuje całokształt instytucji bankowych (banki komercyjne i bank centralny) oraz norm określających ich wzajemne powiązania i stosunki z otoczeniem ${ }^{1}$. Banki komercyjne, zróżnicowane pod względem pełnionych funkcji i zadań, a także realizowanych czynności operacyjnych, tworzą sektor bankowy, który działając na podstawie różnych aktów prawnych, a także ukształtowanej tradycji i kultury bankowości, decyduje o modelu pośrednictwa finansowego w danym kraju².

Kwestia rozwoju sektora bankowego jest nie tylko interesująca sama w sobie, ale przede wszystkim jest ważna w kontekście zależności pomiędzy rozwojem systemu finansowego, w tym bankowego, a wzrostem i rozwojem ekonomicznym. Zasadniczo w teorii i badaniach empirycznych dowodzi się, że rozwój finansowy może stymulować lub hamować wzrost ekonomiczny. Znacznie rzadziej spotkać można natomiast poglądy, iż powyższe kategorie nie pozostają względem siebie w związku przyczynowym ${ }^{3}$. Jeżeli działalność banków prowadzi do lepszej alokacji zasobów w gospodarce, sektor bankowy jest stabilny i efektywny ekonomicznie, to sprzyja to rozwojowi społecznogospodarczemu. Banki zwiększają dobrobyt konsumentów (pozwalając im na korzystniejszy rozkład konsumpcji w czasie) oraz przyczyniają się do wzrostu

\footnotetext{
${ }^{1}$ S. Owsiak: Podstawy nauki finansów, PWE, Warszawa 2002, s. 23.

${ }^{2}$ J. Cichy, B. Puszer (red.): Sektory bankowe w Unii Europejskiej, Wyd. UE w Katowicach, 2016, s. 11.

${ }^{3}$ J. Kulawik: Globalizacja finansowa a funkcjonowanie i rozwój banków, IERiGŻ-PIB, Warszawa 2007 , s. 17.
} 
produkcji i wydajności w całej gospodarce poprzez zasilanie procesów gospodarczych kapitałem ${ }^{4}$.

Z drugiej strony podkreśla się negatywną rolę banków w kontekście ostatniego kryzysu finansowego i gospodarczego (lat 2007-2009). Banki, w sytuacji dobrej koniunktury gospodarczej i napływu znacznych zasobów pieniądza rozwijały inżynierię finansową i stosowały agresywne techniki sprzedaży. Oferowały dostęp do tanich kredytów konsumpcyjnych i skomplikowanych produktów finansowych, nie zwracając dostatecznej uwagi na wiarygodność kredytową klientów oraz ich niską wiedzę na temat nowinek finansowych ${ }^{5}$. Rozwój sektora bankowego jest w interesie społecznogospodarczym, ale doświadczenia ostatniego kryzysu finansowego przekonujac że rozwój ten należy oceniać nie tylko przez pryzmat wielkości sektora bankowego i zakresu jego działalności, ale także przez pryzmat efektywności w realizacji funkcji pośrednictwa finansowego oraz stabilności finansowej.

Głównym celem badań była ocena poziomu rozwoju sektora bankowego w krajach Europy Środkowo-Wschodniej (ESW) na tle przeciętnych charakterystyk sektora w całej Unii Europejskiej (UE) oraz w strefie euro. Dokonano także analizy najważniejszych cech strukturalnych sektorów bankowych w krajach ESW i tendencji ich zmian w latach 2008-2016. W artykule sformułowano hipotezę zakładająca, że dystans w rozwoju sektora bankowego w krajach ESW zmniejsza się w stosunku do średniej dla UE oraz średniej dla strefy euro. Dla weryfikacji tej hipotezy posłużono się syntetycznym wskaźnikiem rozwoju sektora bankowego $\left(S W R_{S B}\right)$. Szczegółowy opis zmiennych przyjętych do badań oraz metody ustalenia wskaźnika syntetycznego znajduje się w dalszej części pracy.

Przez kraje ESW rozumiemy wszystkie kraje Europy Środkowej i Wschodniej, które zostały członkami Unii Europejskiej w roku 2004 (za wyjątkiem Cypru i Malty) oraz w roku 2007 (Bułgaria i Rumunia) i roku 2013 (Chorwacja).

$\mathrm{W}$ analizie porównawczej uwzględniono zmiany, jakie zaszły $\mathrm{w}$ sektorach bankowych poszczególnych krajów (za wyjątkiem Chorwacji) pomiędzy rokiem 2008 a 2016. Źródłem danych empirycznych do badań były statystyki Europejskiego Banku Centralnego (ECB) prezentowane w cyklicznych raportach „EU Banking Structures” $z$ lat 2008-2016 oraz dane Eurostat, European Banking Federation (EBF) i Banku Światowego.

\section{Sektor bankowy w krajach Europy Środkowo-Wschodniej}

W krajach ESW istnieją sektory bankowe, w których działalność bankową prowadzi wiele podmiotów charakteryzujących się zróżnicowaną skalą działania, formą organizacyjno-prawną i strukturą własności. Rozwój sektorów bankowych w krajach ESW był przedmiotem badań m.in. w kontekście ich restrukturyzacji i zmian instytucjonalnych, a także przez pryzmat procesów prywatyzacji rodzimych banków przez duże banki zagraniczne ${ }^{6}$. Analizie poddawano zmiany w strukturze aktywów

\footnotetext{
${ }^{4}$ R. Levine: Finance and Growth: Theory and Evidence, Handbook of Economic Growth, vol. 1/2005, part A; F.S. Mishkin: The Economics of Money, Banking and Financial Markets, 9th ed., Boston 2010.

5 J. Węcławski: Wielkie banki i ich rola w kryzysie finansowym, Annales H. Oeconomia, XLVII/2013, s. 221.

6 S. Barisitz: Banking Transformation 1980-2006 in Central and Eastern Europe-from Communism to Capitalism, South-Eastern Europe Journal of Economics, 2/2009, s. 161-180; R. de Haas, I. van Lelyveld:
} 
sektora, jego zaangażowanie w finansowanie gospodarki, efektywność ekonomicznofinansową oraz procesy konsolidacyjne ${ }^{7}$. Przedmiotem zainteresowania badaczy była także stabilność sektora bankowego w krajach ESW w kontekście światowego kryzysu finansowego ${ }^{8}$.

Tabela 1. Liczba banków w krajach Europy Środkowo-Wschodniej

\begin{tabular}{|c|c|c|c|c|c|c|}
\hline Wyszczególnienie & 2008 & 2010 & 2012 & 2014 & 2016 & $\begin{array}{c}2016 / 2008 \\
(w \%)\end{array}$ \\
\hline Estonia & 17 & 18 & 16 & 37 & 38 & 123,5 \\
\hline Litwa & 84 & 92 & 94 & 89 & 88 & 4,8 \\
\hline Łotwa & 34 & 37 & 29 & 59 & 57 & 67,6 \\
\hline Słowenia & 24 & 25 & 23 & 24 & 19 & $-20,8$ \\
\hline Słowacja & 26 & 29 & 28 & 28 & 29 & 11,5 \\
\hline Chorwacja & - & - & - & 33 & 32 & $-8,6$ \\
\hline Czechy & 54 & 58 & 56 & 56 & 56 & 3,7 \\
\hline Węgry & 197 & 189 & 189 & 189 & 109 & $-44,7$ \\
\hline Polska & 712 & 700 & 695 & 679 & 664 & $-6,7$ \\
\hline Bułgaria & 30 & 31 & 31 & 28 & 27 & $-10,0$ \\
\hline Rumunia & 43 & 41 & 39 & 39 & 37 & $-14,0$ \\
\hline Kraje strefy euro & 441 & 400 & 354 & 306 & 266 & $-39,7$ \\
\hline EU-27/EU-28 & 317 & 306 & 291 & 276 & 276 & $-12,9$ \\
\hline
\end{tabular}

Źródło: EU Banking Structures (ECB), https://www.ecb.europa.eu/pub (dostęp: 10.10.2018 r.)

Liczba banków w każdym $\mathrm{z}$ krajów determinowana jest $\mathrm{m}$. in. wielkością rynku finansowego, a ten $z$ kolei obszarem danego kraju i liczbą ludności ${ }^{9}$. Posługując się liczebnością banków trudno jest porównywać poszczególne krajowe sektory bankowe, jednakże zmiana liczby banków może świadczyć o pewnych tendencjach występujących w sektorze. W krajach Europy Zachodniej od wielu lat obserwujemy procesy konsolidacyjne w sektorze bankowym, tak jest m.in. w Austrii, Danii, Finlandii, Francji, Holandii czy Niemczech ${ }^{10}$. Również w wielu krajach ESW (Słowenia, Węgry, Polska, Bułgaria, Rumunia, Chorwacja) widoczny jest proces konsolidacji sektora bankowego (tab. 1), który przejawia się przez spadek liczby banków. W latach 2008-2016, w krajach ESW spadek liczby banków był nieco mniejszy w porównaniu do Europy Zachodniej, co widoczne jest, gdy spojrzymy na dane dotyczące strefy euro (tab. 1). Wyjątkiem były

Foreign Bank Penetration and Bank Credit Stability in Central and Eastern Europe: Friends or Foes. Research Series Supervision, 58, Netherlands Central Bank 2003.

${ }^{7}$ P. Wiesiołek, D. Tymoczko: Te evolution of banking sectors in Central and Eastern Europe - the case of Poland. BIS Papers, nr 83/2015, s. 313-323; L. Barjaktarović et al.: Development of the Banking Sector in CEE Countries - Comparative Analysis. Journal of Central Banking Theory and Practice, Vol.2/2013, s. 93114; A. Koutsonmanoli-Filippaki, et al.: Efficiency and productivity growth in the banking industry of Central and Eastern Europe, Journal of Banking and Finance, nr 33/2009.

${ }^{8} \mathrm{Z}$ Grubišić, M. Paunović: Effects of macroeconomic and social factors on banking sector development in CEE countries in recession, Finance, Vol. 1-6/2011, s. 200-218; D. Revoltella, F. Mucci: The Prospects for the Banking Market in CESEE Beyond the Crisis [in:] The Future of Banking in CESEE after the Financial Crisis, A. Csajbók, E. Gnan (eds.), SUERF Study 1/2011, Vienna, s. 61-77.

${ }^{9}$ R. Kata, L. Zaręba: Wieloczynnikowa analiza rozwoju rynku bankowości detalicznej w Europie Środkowej i Wschodniej, Studia Ekonomiczne 80/2011, s. 170.

${ }^{10}$ J. Cichy, B. Puszer (red.): Sektory bankowe...... s. 49-586. 
Węgry, gdzie spadek liczby banków przekroczył średnią dla strefy euro. Odmienna sytuacja występowała w takich krajach ESW jak: Estonia, Litwa, Łotwa, Słowacja i Czechy, w których odnotowano wzrost liczby banków, głównie przez napływ banków zagranicznych, działających jako oddziały instytucji kredytowych.

Badanie koncentracji jest jednym z najistotniejszych aspektów diagnozy sytuacji i struktury każdego systemu bankowego. Jednym ze wskaźników miar koncentracji jest wielkość aktywów pięciu największych instytucji kredytowych (CR5). Dla wielu krajów ESW (kraje bałtyckie, Czechy, Słowacja i Chorwacja) wskaźnik ten osiaga znacznie wyższe wartości od średniej dla wszystkich krajów UE oraz dla strefy euro (rys. 1). Spośród krajów ESW wskaźnik CR5 na poziomie niższym, niż średnia dla całej UE odnotowały: Polska, Rumunia, Węgry i Bułgaria.

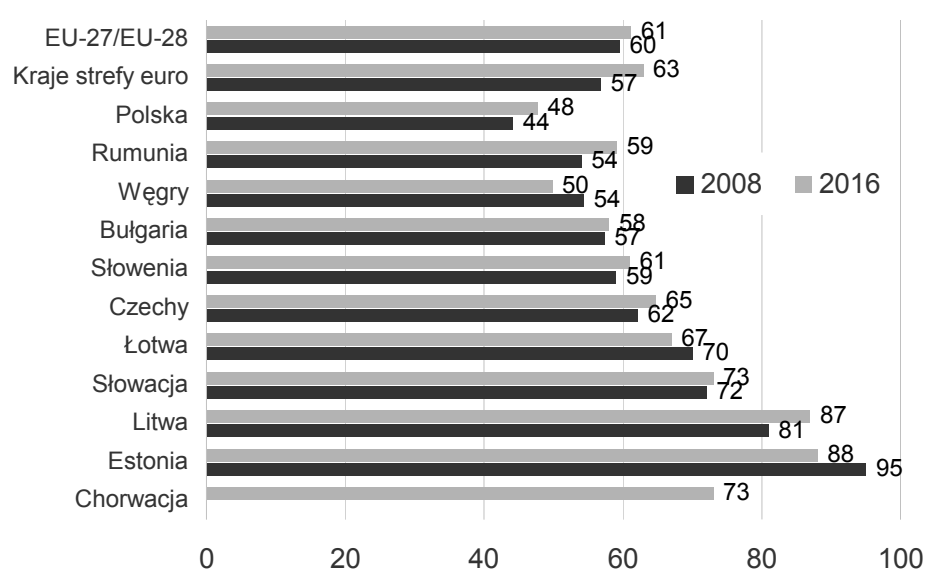

Rysunek 1. Udział 5 największych banków (wskaźnik CR5) w rynku bankowym w krajach Europy Środkowo-Wschodniej (\%) Źródło: jak tabela 1.

W literaturze od dawna toczy się spór, co do stopnia koncentracji sektora bankowego, m.in. w kontekście wpływu koncentracji na stabilność finansową sektora oraz dostęp klientów do usług bankowych, w tym zawłaszcza kredytów ${ }^{11}$. Koncentracja sektora bankowego może sprzyjać jego efektywności ekonomiczno-finansowej, ale z punktu widzenia stabilności sektora tworzy większe ryzyko systemowe. Ponadto zbyt duża koncentracja ogranicza konkurencję na rynku bankowym, co nie jest korzystne dla klientów banków. Należy przyjąć, iż cecha ta jest nominantą w aspekcie rozwoju sektora bankowego, trudno jest jednak jednoznacznie określić, w jakich granicach wskaźnik koncentracji CR5 powinien się utrzymywać, aby najlepiej służyło to rynkowi bankowemu. W dużym stopniu zależy to bowiem od cech strukturalnych sektora bankowego w danym kraju oraz modelu działania banków, w kontekście relacji między

${ }^{11}$ T. Beck, A Demirguc-Kunt, R. Levin: Bank Concentration and Crises, World Bank Policy Research Working Paper 3041/2003, May; F. Allen, D. Gale: Competition and Systemic Stability, Journal of Money, Credit and Banking 36(3)/2004, s. 453-480; A.L. Owen, J.M. Pereira 2018: Bank concentration, competition, and financial inclusion, Review of Development Finance 8/2018, s. 1-17. 
bezpieczeństwem (stabilnością finansową), a ostrą walką o klienta i wzrostem efektywności finansowej.

Kolejnym wskaźnikiem, który stosuje się w ocenie rozwoju sektora bankowego, a zwłaszcza jego wielkości (rozmiaru), jest relacja aktywów instytucji kredytowych do PKB (rys. 2). W krajach takich jak Polska, Czechy i Bułgaria odnotowano znaczący wzrost aktywów banków w relacji do PKB w latach 2008-2016 (od 7 do 21 p.p.). Pomimo to, kraje te nadal znacząco odbiegają od średniej wartości tego miernika dla wszystkich krajów UE oraz dla strefy euro. Podobnie w innych krajach ESW aktywa sektora bankowego są 2-3-krotnie niższe od średniej dla UE i strefy euro (rys. 2). Jest to dowód na wciąż utrzymujące się duże dysproporcje w rozwoju sektora bankowego krajów Europy Środkowo-Wschodniej w stosunku do krajów „starej” UE. Warto jednak zaznaczyć, że dystans pod tym względem zmniejszył się, gdyż w UE jako całości oraz w strefie euro opisywana relacja ulegał zmniejszeniu pomiędzy rokiem 2008 a 2016 o 36 p.p., natomiast w krajach ESW spadki tego wskaźnika były znacząco niższe, albo, jak wspomniano wyżej, nastąpił wzrost aktywów banków w relacji do PKB (rys. 2).

Podobnie jak w przypadku wskaźnika CR5, również w odniesieniu do relacji aktywów sektora do PKB, nie ma pełnej zgody, co do tego, że wyższy poziom tego miernika jest bardziej korzystny dla stabilności finansowej i rozwoju sektora. Duże aktywa sektora bankowego są silnie skorelowane $\mathrm{z}$ występowaniem dużych instytucji finansowych, które prowadzą działalność finansową znacznie wykraczającą poza rynek depozytowo-kredytowy. Rodzi to określone ryzyka, poza tym występuje znany z ostatniego kryzysu finansowego 2007-2009 problem: „za duży żeby upaśč”, ,za ważny żeby upaść" (TBTF, TITF). Z drugiej strony podkreśla się, że duże banki mogą ograniczyć skutki kryzysu finansowego poprzez przejmowanie instytucji w trudnej sytuacji. Jest to również doświadczenie ostatniego kryzysu finansowego ${ }^{12}$.

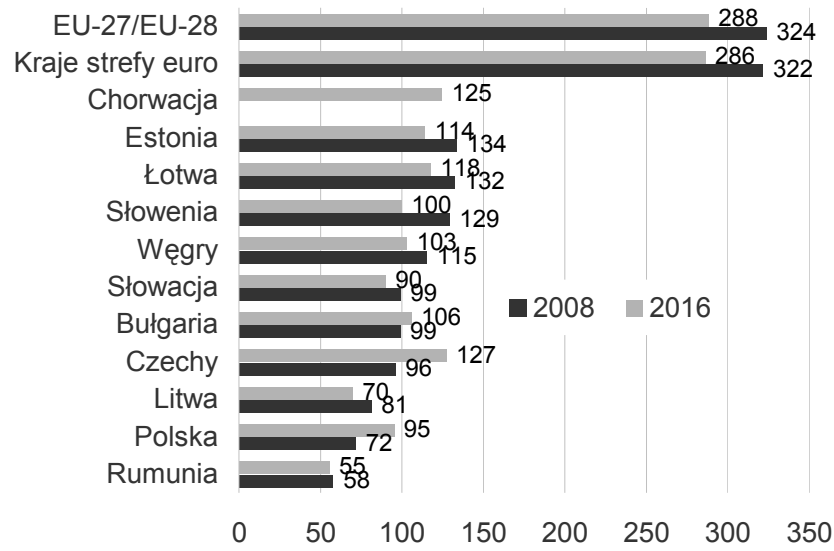

Rysunek 2. Aktywa banków w relacji do PKB (w \%)

Źródło: jak tabela 1.

${ }^{12}$ E. Liikanen: Final Report of the High-level Expert Group on Reforming the Structure of the EU Banking Sector, Brussels 2012. 
Sektor bankowy w krajach ESW - mierzony relacją jego aktywów do PKB - jest wszędzie na tyle mały, że nie ma obawy wystąpienia zagrożeń związanych z nadmiernym ,rozrostem” tego sektora w odniesieniu do realnej gospodarki. Wprost przeciwnie, istnieje spore ryzyko odnoszące się do stabilności finansowej i zrównoważonego rozwoju systemu finansowego, wynikające z niewielkich rozmiarów sektora bankowego. Dlatego zmienną, jaką jest relacja aktywów sektora bankowego do PKB traktujemy w ESW, jako stymulantę rozwoju sektora.

Cechą charakterystyczną krajów ESW jest wysoki udział kapitału zagranicznego w strukturze własności sektora bankowego. Wynika to $\mathrm{z}$ procesów prywatyzacji, jakie miały miejsce w tym sektorze, a także z potrzeby dokapitalizowania banków krajowych. Jest też pochodną liberalizacji przepisów prawnych umożliwiających wzrost zaangażowania inwestorów zagranicznych w lokalny sektor finansowy. W efekcie, udział kapitału zagranicznego w niektórych krajach ESW sięgał w roku 2016 nawet 90\% i więcej (tab. 2). Wyjątkiem pod tym względem są Słowenia i Węgry, gdzie udział wynosi poniżej 50\%. W Polsce w ostatnich latach wskaźnik ten zmniejszal się i na koniec 2017 r. wyniósł 45,5\%.

Tabela 2. Liczba oddziałów banków w przeliczeniu na 100 tysięcy mieszkańców oraz udział kapitału zagranicznego w sektorze bankowym

\begin{tabular}{|c|c|c|c|c|}
\hline \multirow{2}{*}{ Wyszczególnienie } & \multicolumn{3}{|c|}{ Odziały banków na 100 tys. mieszkańców } & \multirow{2}{*}{$\begin{array}{l}\text { Udzial kapitału } \\
\text { zagranicznego } \\
\text { (2016 r.) }\end{array}$} \\
\hline & 2008 & 2016 & $\begin{array}{c}\text { zmiana (w \%) } \\
2016 / 2008\end{array}$ & \\
\hline Estonia & 19,2 & 12,3 & $-35,8$ & 92,0 \\
\hline Litwa & 32,3 & 13,4 & $-58,6$ & 92,3 \\
\hline Łotwa & 32,3 & 14,3 & $-55,8$ & 50,0 \\
\hline Słowenia & 33,9 & 29,5 & $-13,1$ & 46,3 \\
\hline Słowacja & 23,3 & 27,0 & 15,7 & 83,6 \\
\hline Bułgaria & 20,1 & 21,9 & 9,0 & 75,3 \\
\hline Chorwacja & - & 34,4 & - & 90,9 \\
\hline Czechy & 19,0 & 21,3 & 12,4 & 93,2 \\
\hline Węgry & 35,3 & 26,5 & $-24,9$ & 48,0 \\
\hline Polska & 33,5 & 37,6 & 12,3 & 56,6 \\
\hline Rumunia & 34,5 & 23,2 & $-32,9$ & 92,1 \\
\hline Kraje strefy euro & 63,5 & 42,7 & $-32,8$ & 40,8 \\
\hline EU-27/EU-28 & 47,3 & 39,7 & $-16,1$ & 50,2 \\
\hline
\end{tabular}

Źródło: European Banking Federation i World Bank.

Bilans korzyści i zagrożeń wynikających z tak dużego udziału zagranicznych inwestorów w krajowych sektorach bankowych jest różnie oceniany. Z jednej strony zagraniczny kapitał, doświadczenie i technologia tamtejszych banków były niezbędne w procesie przebudowy systemów bankowych i pozwoliły na dynamiczny wzrost poziomu ubankowienia gospodarek ESW, z drugiej zaś strony niekorzystne zachowania banków matek mogą stanowić potencjalne zagrożenie dla krajów goszczących, szczególnie w sytuacjach kryzysowych. Ostatni kryzys finansowy pozwolił na częściową weryfikację tej hipotezy, jak też weryfikację długoterminowej strategii banków zagranicznych w stosunku do tego regionu. Wiele międzynarodowych banków, zwłaszcza te mocno zaangażowane w całym regionie ESW, w okresie kryzysu wykazało determinację i mimo własnych problemów nie wycofało wsparcia dla swoich 
wschodnioeuropejskich spółek córek ${ }^{13}$. Zbytnie uzależnienie od kapitału pozyskanego za pośrednictwem spółki-matki, stało się jednak dodatkowym czynnikiem zagrażającym stabilności banków-córek w krajach goszczących w sytuacji pogorszenia się kondycji finansowej banków-matek. Zagraniczne banki-matki pod wpływem zaleceń Komisji Europejskiej, decydującej o udzieleniu im pomocy publicznej, a także realizując proces delewarowania w odpowiedzi na zaostrzone wymogi kapitałowe, zmodyfikowały swoje strategie wobec regionu ESW, koncentrując się na wybranych rynkach i wycofując z obszarów niestrategicznych. Ich miejsce zajmują inwestorzy zagraniczni, jak i krajowi, a w niektórych krajach także państwo, które za pośrednictwem kontrolowanych przez siebie banków, odpowiada na pojawiające się oferty sprzedaży. W ten sposób kraje te realizuja strategię stopniowego wzmacniania roli kapitału krajowego w sektorze bankowym ${ }^{14}$.

W większości krajów wchodzących w skład UE, w tym zwłaszcza krajów należących do strefy euro, odnotowano w latach 2008-2016 dosyć duży spadek liczby oddziałów bankowych. Jest to efektem postępu technologicznego w bankowości zmierzającego w kierunku ,wirtualizacji” relacji z klientem i samoobsługi klienta poprzez kanały elektroniczne. Proces redukcji placówek bankowych jest także powodowany przez fuzje i łączenia w sektorze (likwidacja oddziałów dublujących się na danym terenie). Przeciętnie w strefie euro w latach 2008-2016 redukcja objęła niemal $1 / 3$ placówek bankowych, zaś w całej UE ponad 16\% (tab. 2). W ESW największe redukcje miały miejsce w krajach bałtyckich, w Rumunii i na Węgrzech. W tym regionie było jednak kilka krajów, w których pomiędzy rokiem 2008 a 2016 przybyło placówek bankowych, były to: Czechy, Polska, Słowacja i Bułgaria (tab. 2).

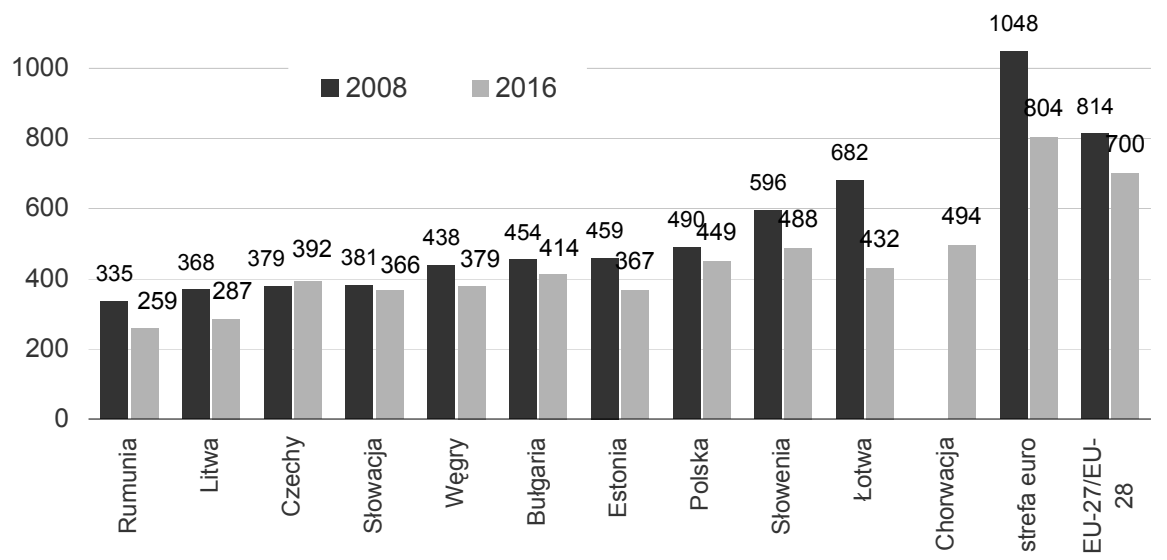

Rysunek 3. Liczba zatrudnionych w sektorze bankowym na 100 tys. mieszkańców Źródło: jak tabela 1.

\footnotetext{
${ }^{13}$ K. Mikołajczyk: Kapitał zagraniczny w bankach krajów Europy Środkowo-Wschodniej - stabilizacja czy eskalacja ryzyka? Wnioski z kryzysu, PTE, Zeszyty Naukowe nr 12, Kraków 2012, s. 119-128.

${ }^{14}$ K. Mikołajczyk: Wptyw struktury własnościowej na strategie banków w krajach Europy ŚrodkowoWschodniej, Annales H - Oeconomia, VOL. L, 4/ 2016, s. 311-323,
} 
Redukcja placówek bankowych była powiązana ze spadkiem zatrudnienia w sektorze bankowym w całej Europie (rys. 3). Proces ten miał miejsce w latach 20082016 nawet w tych krajach ESW, gdzie notowano wzrost liczby oddziałów bankowych, co świadczy o tym, że w efekcie postępu w zakresie bankowości elektronicznej i samoobsługi klientów, tradycyjne placówki bankowe mogły funkcjonować przy mniejszej obsadzie pracowników. Wyniki badań wskazuja, że w latach 2008-2016, udział zatrudnionych w sektorze bankowym na 100 tys. mieszkańców (rys. 3) w krajach ESW był znacznie niższy od średniej dla UE oraz dla strefy euro. Mniejsza liczba placówek bankowych oraz niższe zatrudnienie w sektorze bankowym w krajach ESW, może świadczyć, że dostęp ludności do usług bankowych jest w tej części Europy, gorszy niż w Europie Zachodniej. Skutkuje to także większą skalą wykluczenia finansowego ludności, zwłaszcza z uwagi na dostępność geograficzną do placówek bankowych i infrastruktury finansowej (np. do bankomatów) $)^{15}$.

Czynnikiem istotnym dla stabilności sektora bankowego, ale także świadczącym o efektywności banków w funkcji pośrednictwa finansowego, jest relacja kredytów do depozytów. We wszystkich krajach ESW, za wyjątkiem Czech, wskaźnik ten uległ zmniejszeniu, porównując poziom z roku 2016 do roku 2008 (rys. 4). Jest to przejawem stosowania przez banki polityki ostrożnościowej i konieczności delewarowania, będącej m.in. pokłosiem regulacji wprowadzonych w UE, w odpowiedzi na kryzys finansowogospodarczy lat 2007-2009. Relacja kredytów do depozytów sektora niefinansowego, jest pochodną skali zapotrzebowania na finansowanie zewnętrzne pochodzące $z$ sektora bankowego. W okresie kryzysu gospodarczego w wielu krajach ESW, popyt na kredyt bankowy uległ zmniejszeniu. Z drugiej strony opisywana relacja jest także dowodem podejścia banków do ryzyka. Chodzi nie tylko o ryzyko kredytowe, ale także ryzyko finansowania nadwyżki kredytów nad depozytami długiem zaciągniętym na rynku międzybankowych oraz od spółek-matek.

Spadek wskaźnika kredyty/depozyty niemal we wszystkich krajach ESW, z poziomu często bardzo wysokiego (od 1,14 do 1,88) w 2008 r., do poziomu około 1,0 (za wyjątkiem Estonii i Łotwy), należy ocenić pozytywnie. Świadczy to o większej odpowiedzialności banków za bezpieczeństwo depozytów i odpowiedzialności w działalności kredytowej. Banki dostrzegają konieczność pokrycia akcji kredytowej ze zgromadzonych depozytów i starają się unikać pożyczek na międzynarodowym rynku międzybankowym. Spadek opisywanego wskaźnika dowodzi także większej skuteczność nadzoru bankowego w krajach ESW, w kontekście nie pozwalania bankom-matkom realizować w kraju goszczącym, strategii działalności bankowej o znacznie wyższym poziomie ryzyka, niż ta realizowana $\mathrm{w}$ kraju pochodzenia. Na uwagę zasługuje fakt, że Polska jako jedyny z krajów ESW, zarówno w 2008 r., jak i w 2016 r., charakteryzowała się wartościami wskaźnika kredyty/depozyty niższymi od średniej dla UE i strefy euro. Jest to jeden $\mathrm{z}$ powodów tego, że polski sektor bankowy stosunkowo łagodnie doświadczył skutków kryzysu finansowego.

${ }^{15}$ E. Kempson et al.: Financial Services Provision and Prevention of Financial Exclusion. Eurobarometer report, Personal Finance Research Centre, University of Bristol 2007; European Commission: Financial Exclusion in the EU. New Evidence from the EU-SILC Special Module. Research Note 3, Brussels 2010. 


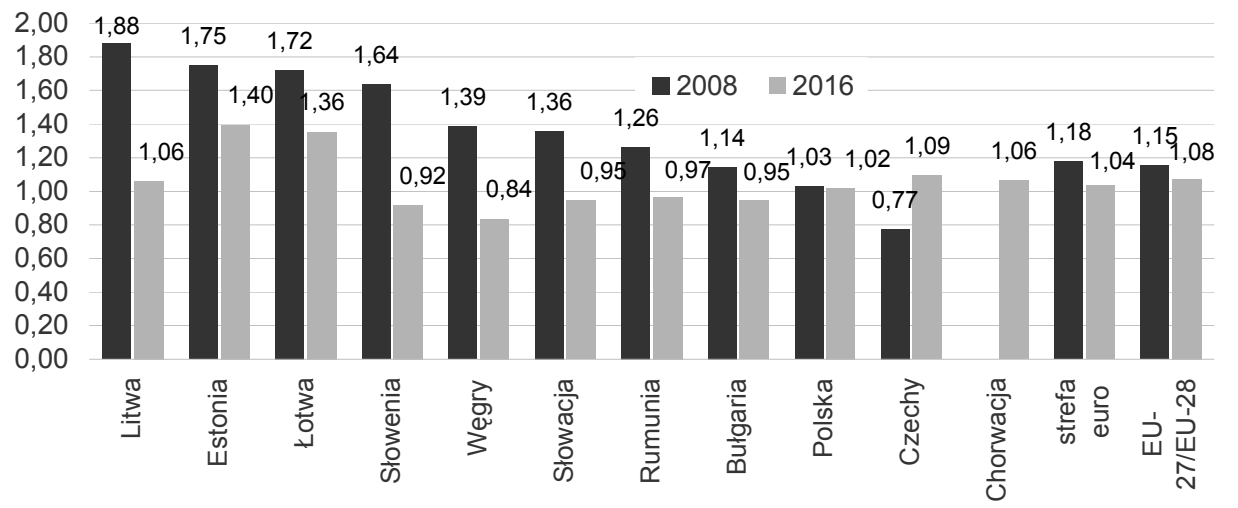

Rysunek 4. Relacja kredyty do depozytów (sektora niefinansowego) Źródło: jak tabela 1.

Kraje ESW, w tym także Polska, charakteryzują się relatywnie niskim poziomem rozwoju rynku kredytów mieszkaniowych (w krajach ESW w 2013 r., wolumen tych kredytów do PKB wynosił od $6,6 \%$ do $22,3 \%$, podczas gdy średnia w UE wynosiła $45 \%$ ). Co prawda, w ostatnich latach dynamika rozwoju tego rynku była wyższa w krajach ESW niż średnio w UE (za wyjątkiem Węgier i Rumunii), niemniej w tym obszarze rynku istnieje duża przestrzeń do wzrostu ${ }^{16}$. Podobnie jest w segmencie kredytów korporacyjnych.

\section{Wieloczynnikowa ocena rozwoju sektora bankowego krajów ESW}

W analizach porównawczych poziomu rozwoju zjawisk złożonych stosuje się metody analizy wieloczynnikowej. W niniejszym badaniu zastosowano metodę wzorca rozwoju, na podstawie której obliczono syntetyczny wskaźnik rozwoju sektora bankowego $\left(S W R_{S B}\right)$ dla każdego z krajów ESW oraz średnią wartość tego miernika dla krajów UE i strefy euro. W opracowaniu algorytmu wskaźnika $S W R_{S B}$ wzorowano się na miarze poziomu rozwoju systemu finansowego zaproponowanej przez MFW, określanej jako wskaźnik rozwoju systemu finansowego (Financial Development Index - FD) ${ }^{17}$.

Metoda wzorca rozwoju należy do grupy metod porządkowania liniowego, których celem jest uszeregowanie obiektów w kolejności od najlepszego do najgorszego pod względem poziom zjawiska złożonego ${ }^{18}$. Zastosowanie tej metody pozwala nie tylko na ustalenie rankingu obiektów, ale umożliwia także ocenę skali zróżnicowania badanego zjawiska. Rozwój sektora bankowego oceniany był przez pryzmat cech, które podzielone zostały na dwie grupy (tab. 3). Pierwsza $z$ nich (5 cech) zawiera zmienne opisujące

\footnotetext{
${ }^{16}$ R. Kata: Kredyty hipoteczne w Polsce w kontekście stabilności finansowej i makroekonomicznej, Nauki Ekonomiczne XXII, PWSZ w Płocku, 2015, s. 186.

${ }^{17}$ Wskaźnik FD będący miarą rozwoju instytucji finansowych i rynków finansowych zawiera trzy komponenty (subwskaźniki): rozmiar/wielkość (Depth), dostępność (Access) i efektywność (Efficiency), dla których wartości obliczane są w oparciu o zestaw wybranych mierników cząstkowych [Zob. Rozwój systemu finansowego w Polsce w 2014 r., NBP, Warszawa 2015, s. 32-35].

${ }_{18}$ G. Kowalewski: Metody porządkowania liniowego [w:] J. Dziechciarz (red.), Ekonometria, metody, przykłady, zadania, Wyd. AE we Wrocławiu, Wrocław 2003, s. 287.
} 
wielkość sektora bankowego oraz dostępność usług bankowych dla mieszkańców danego kraju. Druga grupa (7 zmiennych) zawiera cechy stanowiące o efektywności ekonomicznej i stabilności finansowej sektora bankowego. W efekcie wybrano 12 zmiennych diagnostycznych o różnym charakterze, tj. będących stymulantami rozwoju sektora, nominantami bądź destymulantami (tab. 3).

Tabela 3. Wskaźniki cząstkowe wykorzystane w algorytmie syntetycznego wskaźnika rozwoju sektora bankowego $\left(S W R_{S B}\right)$

\begin{tabular}{|l|l|c|}
\hline \multicolumn{1}{|c|}{$\begin{array}{c}\text { Obszar } \\
\text { analizy }\end{array}$} & \multicolumn{1}{|c|}{ Zmienna (cecha) } & $\begin{array}{c}\text { Charakter } \\
\text { zmiennej }\end{array}$ \\
\hline $\begin{array}{l}\text { Rozmiar/wiel } \\
\text { kość oraz } \\
\text { dostępność }\end{array}$ & $\mathrm{X}_{1}$ - Aktywa sektora bankowego w relacji do PKB (\%) & stymulanta \\
& $\mathrm{X}_{3}$ - Aktywa banków na 1 zatrudnionego w sektorze (tys. euro) & stymulanta \\
& $\mathrm{X}_{4}$ - Liczba oddziałów na 100 tys. mieszkańców & stymulanta \\
& $\mathrm{X}_{5}$ - Liczba bankomatów w przeliczeniu na 100 tys. mieszkańców & stymulanta \\
& $\mathrm{X}_{6}$ - Koncentracja rynku (wskaźnik CR5) & nominanta \\
\hline Efektywność & $\mathrm{X}_{7}$ - Wskaźnik kredyty/depozyty & nominanta \\
i stabilność & $\mathrm{X}_{8}-$ Współczynnik kapitału Tier 1 (\%) & nominanta \\
& $\mathrm{X}_{9}$ - Wskaźnik kredytów zagrożonych (\%) & stymulanta \\
& $\mathrm{X}_{10}$ - Udział kredytów dla sektora niefinansowego w aktywach ogółem (\%) \\
& $\mathrm{X}_{11}-$ Udział depozytów klientów (sektora niefinansowego) w sumie & stymulanta \\
& \multicolumn{1}{|c|}{ bilansowej (\%) } \\
& $\mathrm{X}_{12}$ - Wynik finansowy na zatrudnionego (w tys. euro) & stymulanta \\
\hline
\end{tabular}

Źródło: opracowanie własne

Stymulanty są to zmienne, których wysokie wartości w badanych obiektach są pożądane z punktu widzenia rozpatrywanego zjawiska (np. aktywa sektora $\mathrm{w}$ relacji do PKB, zatrudnienie w sektorze). Destymulanty to takie wskaźniki, których spadek jest pozytywnym trendem $\mathrm{w}$ rozwoju zjawiska. W niniejszej analizie jako destymulantę przyjęto wskaźnik kredytów zagrożonych. Nominantami są zmienne, których odchylenia wartości w badanym obiekcie od wartości (lub przedziału wartości) uznawanych za najkorzystniejsze są niepożądane z punktu widzenia rozpatrywanego zjawiska.

$\mathrm{W}$ metodzie wzorca rozwoju przyjmuje się, że wartości zmiennych są znormalizowane. Ujednolicenie charakteru zmiennych polega najczęściej na zamianie (stymulacji) destymulant $\mathrm{i}$ nominat na stymulanty ${ }^{19}$ [Młodak 2006]. Stymulacji destymulant i nominant dokonywano według formuły różnicowej, która dla destymulant ma następującą postać:

$$
x_{i j}^{S}=a-b x_{i j}^{D}, \quad i=1,2, \ldots, n ; j=1,2, \ldots m ; \quad b>0,
$$

gdzie: $a, b-$ stałe przyjmowane w sposób arbitralny, $b=1, a=\max _{i}\left\{x_{i j}^{D}\right\}$.

Formuła różnicowa stymulacji nominant przyjmuje zaś postać:

$$
x_{i j}^{S}=-\left|x_{i j}^{N}-x_{j}^{N}\right|, \quad \quad i=1,2, \ldots, n ; j=1,2, \ldots m .
$$

gdzie: $x_{j}^{N}$ - nominalna (pożądana) wartość $j$-tej zmiennej,

$x_{i j}^{N}$ - wartość $j$-tej zmiennej w $i$-tym obiekcie.

${ }^{19}$ A. Młodak: Analiza taksonomiczna w statystyce regionalnej, DIFIN, Warszawa 2006. 
Do analizy rozwoju sektora bankowego w krajach ESW wykorzystano trzy nominanty. Pierwsza $\mathrm{z}$ nich to wskaźnik koncentracji sektora CR5, dla którego wyznaczono wartość optymalną równą $60 \%$. Kolejna, to wskaźnik kredytów do depozytów (sektora niefinansowego), dla którego ustalono optimum równe 1,0, czyli gdy wartość udzielonych przez banki kredytów w 100\% znajduje pokrycie w zgromadzonych depozytach. Ostatnią zmienną należącą do grupy nominant jest współczynnik kapitału podstawowego Tier 1 (inaczej CET1), który informuje o wielkości kapitału służącego do pokrywania strat $\mathrm{w}$ warunkach wypłacalności banku. Kapitał ten pozwala bankowi kontynuować normalną działalność i zapewnia mu płynność finansowa $a^{20}$. Według dyrektywy UE w sprawie wymogów kapitałowych CRD IV, minimalny poziom kapitału Tier 1 powinien wynosić 4,5\% aktywów ważonych ryzykiem, jednakże na potrzeby niniejszej analizy przyjęto wartość 2-krotnie większą (9\%), gdyż wyższy poziom Tier 1 jest dowodem na większą stabilność finansową sektora bankowego.

W kolejnym etapie analizy, dla poszczególnych zmiennych wyznacza się abstrakcyjny obiekt, tzw. wzorzec rozwoju $\mathrm{x}_{w}$ o najlepszych wartościach dla danej cechy. Następnie bada się podobieństwo obiektów (krajów) do owego najlepszego obiektu przez obliczenie odległości każdego obiektu od wzorca rozwoju. Wszystkie zmienne diagnostyczne reprezentujące poziom rozwoju sektora bankowego (jego rozmiar, dostępność i efektywność) w wyniku stymulacji zyskały charakter stymulant. Za wzorzec dla każdej zmiennej $x_{i j}$ przyjęto zatem wartość maksimum dla tej zmiennej (przy czym dla nominant maksimum to wartość przyjęta jako optymalna). Następnie cechy diagnostyczne poddano standaryzacji w celu ujednolicenia charakteru zmiennych i sprowadzenia ich wartości do przedziału $[0 ; 1]$. W tym celu wykorzystano formułę [Młodak 2006]:

$$
z_{i j t}=\frac{x_{i j t}}{\max _{j, t}\left[x_{i j t}\right]}
$$

gdzie: $x_{i j t}$ oznacza wartość $i$-tej stymulanty $($ dla $i=1,2, \ldots, n)$ w $j$-tym kraju $(j=$ $1,2, \ldots, 16)$ w roku $t$, zaś $z_{i j t}$ oznaczają wartości kolejnych wystandaryzowanych stymulant.

Ostatnim krokiem było wyznaczenie dla każdego obiektu (kraju) syntetycznego wskaźnik rozwoju sektora bankowego $S W R_{S B}$, czyli tzw. miary rozwoju. Przyjęto założenie, że wszystkie miary cząstkowe wpływające na rozwój sektora bankowego mają taką samą wagę, czyli taki sam wpływ na poziom zjawiska złożonego (wskaźnika $\left.S W R_{S B}\right)$. Wartość wskaźnika $S W R_{S B}$ w $i$-tym kraju ustalono ze wzoru:

$$
\mathrm{SWR}_{\mathrm{SBi}}=\frac{\sum_{\mathrm{j}=1}^{\mathrm{k}} \mathrm{z}_{\mathrm{ij}}}{12}
$$

Przy zastosowaniu tej metody syntetyczny wskaźnik rozwoju sektora bankowego $\left(S W R_{S B}\right)$ mieści się w przedziale $[0,1]$.

\footnotetext{
${ }^{20}$ A. Mastalerz: Wpływ regulacji Bazylei III na kapitał regulacyjny sektora bankowego w Polsce, Przegląd Zachodniopomorski 28(53), nr 3/2013, s. 199.
} 
Wartości syntetycznego wskaźnika rozwoju sektora bankowego dla krajów ESW dowodzą, iż dystans, jaki dzieli te kraje w odniesieniu do średniej dla UE i średniej dla strefy euro jest ciagle dość duży (rys. 5). Porównując wartość wskaźnika $S W R_{S B}$ w roku 2008 i 2016 widać, że w większości krajów ESW oraz w strefie euro nastapił jego wzrost, natomiast przeciętna wartość $S W R_{S B}$ dla całej UE nieznacznie spadła (o 0,02). Wzrost notowany w takich krajach jak: Estonia, Czechy, Litwa, Słowacja, Polska i Słowenia był jednak większy, niż w strefie euro. Oznacza to, że kraje te zmniejszyły dystans w rozwoju sektora bankowego w stosunku do najbardziej rozwiniętych pod tym względem krajów Europy Zachodniej. W tych krajach zachodzi zatem konwergencja w tym obszarze. W pozostałych krajach regionu ESW, wzrostu wskaźnika $S W R_{S B}$ w roku $2016 \mathrm{w}$ stosunku do roku 2008 był mniejszy, i pozwolił jedynie na zmniejszenie dystansu w stosunku do średniej dla UE. Jedynym krajem, który zanotował spadek wskaźnika $S W R_{S B}$ była Bułgaria. Warto zauważyć, że generalnie dysproporcje w rozwoju sektora bankowego w krajach ESW uległy zmniejszeniu, o czym świadczy rozstęp wskaźnika $S W R_{S B}$, który w 2008 r. wynosił 0,17, zaś w 2016, już tylko 0,12. Kraje, dla których wskaźnik rozwoju sektora bankowego jest najbliższy średniej dla UE i średniej dla strefy euro to: Słowenia, Polska, Słowacja i Chorwacja (rys. 5).

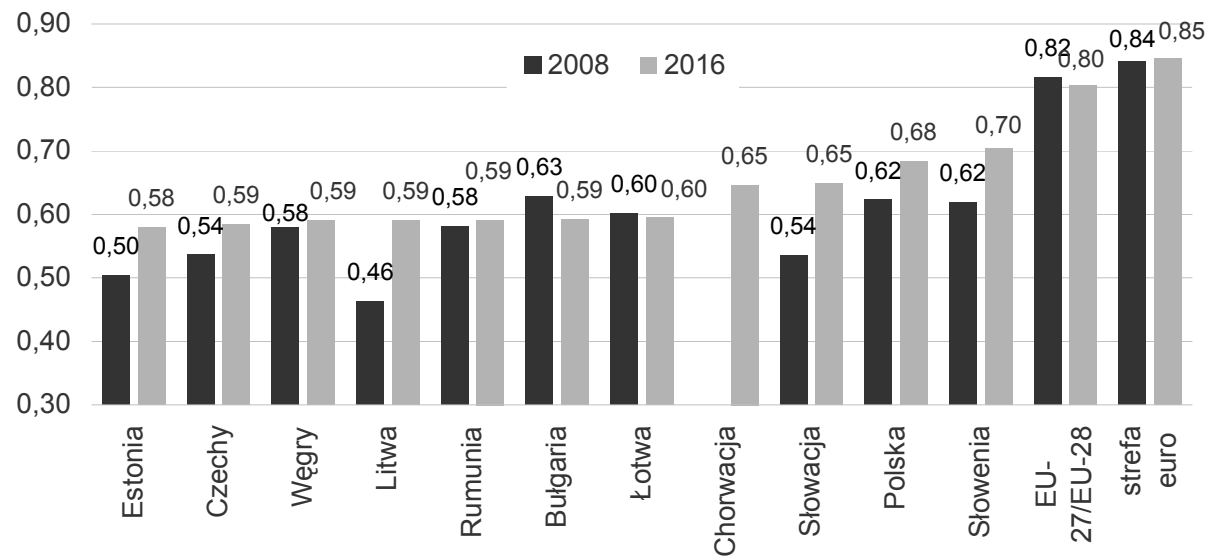

Rysunek 5. Syntetyczny wskaźnik rozwoju sektora bankowego $S W R_{S B}$ krajów Europy ŚrodkowoWschodniej w porównaniu do średniej UE i strefy euro Źródło: obliczenia własne.

\section{Podsumowanie}

Kraje Europy Środkowo-Wschodniej przeszły długą droge od czasu transformacji ustrojowej, kiedy utworzyły, reaktywowały lub głęboko zreformowały wszystkie elementy systemu finansowego. Sektor bankowy, będący jego najbardziej istotnym i wrażliwym elementem, ukształtował się pod wpływem przyjętego modelu prywatyzacji, rozwiązań regulacyjnych i systemowych. W ostatniej dekadzie na jego kształt wpłynął także kryzys finansowy, problemy niektórych dużych banków zagranicznych inwestujących w sektor bankowy w regionie ESW oraz unijne postkryzysowe regulacje. 
Kraje ESW, za wyjątkiem Bułgarii, sukcesywnie zmniejszają dystans rozwojowy, jaki dzieli ich rodzime sektory bankowe w stosunku do średniej w całej UE. Największy postęp w tym zakresie, pomiędzy rokiem 2008 a 2016 poczyniły takie kraje jak: Słowacja, Słowenia, Polska oraz Łotwa i Estonia. Wieloczynnikowa analiza rozwoju sektora bankowego dla roku 2016 wskazuje jednak, że wciąż dystans pod tym względem, pomiędzy wymienionymi krajami, i tym bardziej pozostałymi krajami regionu, a krajami Europy Zachodniej jest dosyć duży. Różnice pod względem rozwoju sektora bankowego w obrębie regionu Europy Środkowo-Wschodniej uległy jednak znacznemu zmniejszeniu.

Wyniki badań wskazują, że cechy, w obszarze których kraje ESW osiągają zbliżone wartości do średniej dla UE, czy też średniej dla strefy euro, dotyczą efektywności ekonomicznej i stabilności finansowej sektora. Może to wynikać z faktu, że kraje ESW nie doświadczyły tak poważnych skutków kryzysu finansowego i kryzysu w strefie euro (kryzys zadłużeniowy krajów PIIGS), jak kraje „starej” UE. Dużo gorzej, na tle krajów UE-15 kształtują się zmienne opisujące wielkość sektora oraz dostępność usług bankowych dla klientów. W tym obszarze należy zatem upatrywać największych możliwości postępu w procesie konwergencji sektorów bankowych krajów Europy Środkowo-Wschodniej.

\section{Bibliografia}

Allen F., Gale D.: Competition and Systemic Stability, Journal of Money, Credit and Banking 36(3), 2004.

Barisitz S.: Banking Transformation 1980-2006 in Central and Eastern Europe-from Communism to Capitalism, South-Eastern Europe Journal of Economics, 2/2009.

Barjaktarović L., Paunović M., Ječmenica D.: Development of the Banking Sector in CEE Countries - Comparative Analysis. Journal of Central Banking Theory and Practice, Vol.2/2013.

Beck T., Demirguc-Kunt A, Levine R.: Bank Concentration and Crises, World Bank Policy Research Working Paper 3041, May 2003.

Cichy J., Puszer B., (red.): Sektory bankowe w Unii Europejskiej, Wyd. Uniwersytetu Ekonomicznego w Katowicach, Katowice 2016.

De Haas R., van Lelyveld I.: Foreign Bank Penetration and Bank Credit Stability in Central and Eastern Europe: Friends or Foes? Research Series Supervision 58, Netherlands Central Bank 2003. European Commission: Financial Exclusion in the EU. New Evidence from the EU-SILC Special Module. Research Note 3, Brussels 2010.

Grubišić Z, Paunović M.: Effects of macroeconomic and social factors on banking sector development in CEE countries in recession, Finance, Vol. 1-6/2011.

Kata R., Zaręba L.: Wieloczynnikowa analiza rozwoju rynku bankowości detalicznej w Europie Środkowej i Wschodniej, Studia Ekonomiczne 80/2011.

Kata R.: Kredyty hipoteczne w Polsce w kontekście stabilności finansowej i makroekonomicznej, Nauki Ekonomiczne XXII, PWSZ w Płocku, Płock 2015.

Kempson E, Crame M., Finney A.: Financial Services Provision and Prevention of Financial Exclusion. Eurobarometer report, Personal Finance Research Centre, University of Bristol, 2007. Koutsonmanoli-Filippaki A., Margaritas D., Staikoura C.: Efficiency and productivity growth in the banking industry of Central and Eastern Europe, Journal of Banking and Finance, nr 33/2009. Kowalewski G.: Metody porzqdkowania liniowego [w:] J. Dziechciarz (red.), Ekonometria, metody, przyktady, zadania, Wyd. AE we Wrocławiu, Wrocław 2003.

Kulawik J.: Globalizacja finansowa a funkcjonowanie i rozwój banków, IERiGŻ, Warszawa 2007. 
Levine R., 2005: Finance and Growth: Theory and Evidence, Handbook of Economic Growth, vol. 1, part A, 2005. doi.org/10.1016/S1574-0684(05)01012-9

Liikanen E.: Final Report of the High-level Expert Group on Reforming the Structure of the EU Banking Sector, Brussels 2012.

Mastalerz A.: Wplyw regulacji Bazylei III na kapitat regulacyjny sektora bankowego w Polsce, Przegląd Zachodniopomorski 28(53), nr 3/1, 2013.

Mikołajczyk K.: Kapital zagraniczny w bankach krajów Europy Środkowo-Wschodniej stabilizacja czy eskalacja ryzyka? Wnioski z kryzysu, PTE, Zeszyty Naukowe nr 12, Kraków 2012.

Mikołajczyk K.: Wptyw struktury własnościowej na strategie banków $w$ krajach Europy Środkowo-Wschodniej, Annales H - Oeconomia, VOL. L, 4, 2016, doi:10.17951/h.2016.50.4.311

Mishkin F.S.: The Economics of Money, Banking and Financial Markets, 9th ed., Boston 2010.

Młodak A.: Analiza taksonomiczna w statystyce regionalnej, DIFIN, Warszawa 2006.

NBP: Rozwój systemu finansowego w Polsce w 2014 r., NBP, Warszawa 2015.

Owen A.L., Pereira J.M.: Bank concentration, competition, and financial inclusion, Review of Development Finance 8/2018.

Owsiak S.: Podstawy nauki finansów, PWE, Warszawa 2002.

Revoltella D., Mucci F.: The Prospects for the Banking Market in CESEE Beyond the Crisis [in:] The Future of Banking in CESEE after the Financial Crisis, A. Csajbók, E. Gnan (eds.), SUERF Study 1, Vienna 2011.

Węcławski J.: Wielkie banki i ich rola w kryzysie finansowym, Annales H - Oeconomia, XLVII/1, 2013.

Wiesiołek P., Tymoczko D.: The evolution of banking sectors in Central and Eastern Europe - the case of Poland. BIS Papers, nr 83/2015.

\section{Summary}

The main purpose of the article was to determine the level of development of the banking sector in the countries of Central and Eastern Europe (CEE) and compare it to the average level of the European Union and the euro area. The analysis covered variables concerning the size of the sector, availability of banking services, as well as economic efficiency and stability of the sector. The synthetic development index of the banking sector calculated on their basis shows that the diversification in the development of the banking sector between the CEE countries is diminishing. In 2008-2016, most of the region's countries have also reduced the distance in the development of the sector in relation to the average in the European Union.

Key words: banking sector, Central and Eastern European countries

Informacja o autorach

dr hab. Ryszard Kata, prof. UR

Uniwersytet Rzeszowski, Wydział Ekonomii

Katedra Rynków Finansowych i Finansów Publicznych

e-mailrdkata@univ.rzeszow.pl

ORCID: 0000-0001-6085-3935

mgr Justyna Chmiel

Uniwersytet Rzeszowski, Wydział Ekonomii

Katedra Finansów i Rachunkowości

e-mail: j.chmiel@ur.edu.pl

ORCID: 0000-0002-3890-2785 